\title{
Cytotoxic Activity of Daucane Sesquiterpene Esters Isolated From Endemic Ferula tenuissima HUB. MOR\& PEŞMEN
}

Fadime Aydoğan, Şura Baykan, Bilge Debeleç Bütüner

${ }^{1}$ Department of Pharmaceutical Botanic, Faculty of Pharmacy, Ege University, 35100, Izmir, Turkey

${ }^{2}$ Department of Pharmaceutical Biotechnology, Faculty of Pharmacy, Ege University, 35100, Izmir,

\begin{abstract}
Objectives: Phytochemical study of endemic Ferula tenuissima roots and determination of the cytotoxic activity of pure compounds on PC-3.
\end{abstract}

Materials and Methods: Air-dried and powdered roots of $F$. tenuissima $(1 \mathrm{~kg})$ were extracted respectively with $n$-hexane, chloroform $\left(\mathrm{CHCl}_{3}\right)$ and methanol $(\mathrm{MeOH})(3 \times 2$ $\mathrm{L}$, each) by sonication at $30^{\circ} \mathrm{C}$, for $24 \mathrm{~h}$. The extracts were then filtered. The solvents separately evaporated under reduced pressure to dryness. Compounds were isolated by chromatographic methodes and structures of compounds were determined by spectral methodes (1D-, 2D NMR and LC-MS). Compounds were tested for their cytotoxic activities versu PC-3 cell line by WST assay.

Results: Phytochemical investigation of dried roots of endemic F. tenuissima performed and three sesquiterpene esters were isolated. As teferidin, ferutinin and elaocyhtrin-A; daucane-type sesquiterpenes were identified. In the bioactivity study, Ferutinin exhibitited the highest cytotoxic activity with $19.7 \mu \mathrm{M} I \mathrm{IC}_{50}$ value.

Conclusion: The results indicate that the main compounds of Ferula tenuissima roots are daucane sesquiterpenes and ferrutinin has potential effect on PC-3 cells.

Key words: Ferula tenuissima; daucane sesquiterpene esters; cytotoxicity; prostate cancer. 


\section{Endemik Ferula tenuissima HUB. MOR \& PEŞMEN' den İzole Edilen Daukan Seskiterpen Esterlerinin Sitotoksik Etkisi}

\section{ÖZ}

Giriş Ve Amaç: Endemik Ferula tenuissima köklerinin fitokimyasal yönden incelenmesi ve elde edilen saf bileşiklerin PC-3 üzerinde sitotoksik etkilerinin belirlenmesidir.

Yöntem Ve Gereçler: F. tenuissima 'nın açık havada kurutulmuş ve toz haline getirilmiş kökleri (1 kg , 24 saat boyunca $30^{\circ} \mathrm{C}$ ' de sonikasyonda n-hekzan, kloroform $\left(\mathrm{CHCl}_{3}\right)$ ve metanol $(\mathrm{MeOH})(3 \times 2 \mathrm{~L}$, her biri) ile sırasıyla ekstre edildi. Ekstraklar daha sonra süzüldü. Sıvı ekstreler, vakum altında kuruluğa kadar uçuruidu. Kromatografik yöntemler ile bileşikler elde edildi ve bileşiklerin yapıları spektral yöntemler ile belirlendi (1D-, 2D NMR and LC-MS). Bileşiklerin PC-3 üzerindeki sitotoksik aktiviteleri WST yöntemi ile test edildi.

Bulgular: Endemik F. tenuissima' nın kurutulmuş köklerinin fitokimyasal incelemesi yapıldı ve üç seskiterpen esteri izole edildi. Teferidin, ferutinin ve elaeochytrin-A daukan tip seskiterpen esterleri olarak belirlendi. Biyoaktivite çalışmasında, Ferutinin en yüksek sitotoksik aktiviteyi IC50. 19.7 MM ile gösterdi.

Sonuç: Sonuçlar Ferula te huissima köklerinin ana bileşiklerinin daukan seskiterpenler ve ferutininin PC-3 hücreleri üzerinde potansiyel bir etkiye sahip olduğunu göstermektedir.

Anahtar kelimeler: Ferula tenuissima, daukan seskiterpen ester, sitotoksite, prostat kanseri 


\section{INTRODUCTION}

In recent years, cancer is the main cause of public health probems and the second leading cause of the death in the world despite their advanced imaging and molecular diagnostic techniques. ${ }^{1}$ Prostate cancer is the most common cancer in men and is the second leading cause of cancer deaths in the United States after lung cancer. ${ }^{1}$ Todays, most cancer drugs used as cytotoxic agents are obtained directly from natural products like plants, marine organisms and microorganisms or indirectly by their semi-synthesis of molecules from this sources. As a result, cancer research on natural products is expanding. ${ }^{2}$

The genus Ferula L. of the Apiaceae (Umbelliferae) family is represented by about 185 species in the world and 23 taxa in Turkey. ${ }^{3}$ Several species, such as roots of $F$. gummosa, F. asafeotida have been used in folk medicine as an antidote in poisonings, aphrodisiac, antimicrobial, expectorant and antihemorrhoid, as well as to treat stomachache, colitis in infants, asthma, urinary trâct disorders. ${ }^{4}$ Monoterpenes, sesquiterpenes (especially daucanes, humulanes, and guaianes type sesquiterpene esters, sesquiterpene lactones), coumarins were found to be the main constituents of the Ferula genus by phytochemical studies. ${ }^{5-8}$ Phenylpropanoid, sulphur containing derivates, triterpenes and their glycosides were also reported. ${ }^{9-11}$ Recent pharmacological research has demonstrated that different extracts of Ferula species contain sesquiterpene derivatives have in particular proven to be cytotoxic on several cancer cell lines.2,12 In addition, the extracts have been reported to have antimicrobial, antihelminthic anticonvulsant, antispasmodic, antihyperglicemic, antihyperlipidemic and antioxidant activities. ${ }^{13-18}$

\section{EXPERIMENTAL}

Plant Material

The roots of $F$. tenuissima HUB. MOR\& PEŞMEN were collected in Yarpuz Region, Osmaniye, Turkey $(940 \mathrm{~m}$ ) in June 2013. The whole plant was identified by Assoc. Prof. Serdar Gokhan Senol from Section of Botany, Department of Biology, Faculty of Science, Ege University. A voucher specimen (IZEF 6046) was deposited in the Herbarium of Ege University, Faculty of Pharmacy, Izmir, Turkey (www.izef.ege.edu.tr) 


\section{Extraction and isolation}

Air-dried and powdered roots of $F$. tenuissima $(1 \mathrm{~kg})$ were extracted respectively with n-hexane, chloroform $\left(\mathrm{CHCl}_{3}\right)$ and methanol $(\mathrm{MeOH})(3 \times 2 \mathrm{~L}$, each) by sonification at $30{ }^{\circ} \mathrm{C}$, for $24 \mathrm{~h}$. The extracts were then filtered. The solvents separately evaporated under reduced pressure to dryness. Yields were $44.31 \mathrm{~g}, 9.90 \mathrm{~g}$ and $45.89 \mathrm{~g}$ respectively. 9.27 of the $\mathrm{CHCl}_{3}$ extract was submitted to silica gel column chromatography eluted respectively with n-hekzan: EtOAc gradient (100:00:100,v/v,\%10 decreasing polarity, each $500 \mathrm{ml})$, EtOAc: Acetone (100:0 $0: 100, v / v, \% 10$ decreasing polarity) and then Acetone:MeOH (100:0-0:100,v/v,\%10 decreasing polarity) to give 15 fractions; named A-O and monitored by $T L C$. Based on TLC profiles 3 fractions; Fractions $B(210 \mathrm{mg}), E(233 \mathrm{mg})$ and G (200 mg) were selected for further purification. Fraction $B$ was chromatographed over silica gel column (150 g) with n-hekzan: EtOAc (100:0-87.5:12.5, with \%2.5 icreasing polarity), to afford five fractions (B1-B5). Fractions B3 $(83 \mathrm{mg})$ was rechromatographed over silica gel column (75 g) with n-hekzan: EtOAc (100:0-90:10,\%2 decreasing polarity), to yield Compound 1 (40 mg) purely. $33 \mathrm{mg}$ of Fraction E; was further purified by preperatif TLC. (n-hekzan: EtOAc, 80:20, silica gel) and isolated and yielded $17 \mathrm{mg}$, Compound 3. Fraction $G$ was submitted to silicagel column chromatography eluted with n-hekzan:EtOAc (95:5-50:50; \%5 increasing polarity) solvent and yielded Compound 2 (33 mg).

Cytotoxicity assay and cells

Cell toxicity was analysed by using WST-1 according to the manufacturer's protocol. PC-3 and RWPE-1 cell lines were obtained from American Type Culture Collection (ATCC Manassas, VA). PC3 cells were propagated using DMEM F-12 supplemented with $5 \%$ FBS, L-glutamine $(2 \mathrm{mM})$, penicillin $(100 \mathrm{U} / \mathrm{mL})$ and streptomycin $(100 \mu \mathrm{g} / \mathrm{mL})$ while RWPE-1 cells were propagated in keratinocyte growth medium supplemented with bovine pituitary extract and $5 \mu \mathrm{M}$ EGF at $37{ }^{\circ} \mathrm{C}$ with $5 \% \mathrm{CO}_{2}$. Molecules were dissolved in DMSO and treatments were done as DMSO volume will not exceed $0.5 \%$ of the culture media volume. Control cells were treated with the same volume of DMSO used during the molecule treatments. PC-3 '(8x103)' and RWPE-1 cells '(104)' were seeded and grown in 96-well plates and incubated for 24 hours. Molecule treatments were performed for 48 hours and WST1 cell proliferation reagent (Roche Cat No: 05015944001) was used as recommended. Briefly, WST1 (1:10 final dilution) was added onto the cells at the end of treatments, and the cells were incubated for an 
additional 3 hours. At the end of the incubation, absorbance was measured at 450 and $690 \mathrm{~nm}$ using a SpectraMaxPlus 384 spectrophotometer (Molecular Devices). IC 50 concentrations of the molecules were calculated through nonlinear regression analysis of Graphpad Prism 6. All experiments were performed in triplicate. Doxorobucin was used as the positive control.

\section{Chemicals and Other Materials}

Mass spectra (Thermo-Scientific TSQ Quantum Access Max LC-MS/MS, ESI). Nuclear magnetic resonance (NMR) spectra were recorded on Varian Oxford AS400 and Bruker DRX-500. The chemical shifts were measured relative to the residual solvent peak and are expressed in $\delta(\mathrm{ppm})$ and the coupling constant $(\mathrm{J})$ are reported in Hertz $(\mathrm{Hz})$. Column chromatography was carried out on silica gel 60 (40-63 mm-Merck), Sephadex LH-20 (GE Healthcare) and Lichroprep RP-18 (25-40 mm, Merck) using analytical grade purity solvents (Merck and Sigma). TLC analyses were carried out on silica gel 60 F254 and RP-18 F254s (Merck) precoated aluminium plates. Compounds were detected by UV (244- $366 \mathrm{~nm})$ and $\% 10$ vanillin ethanol solution/ $/ \mathrm{H}_{2} \mathrm{SO}_{4}$ reagent followed by heating $105^{\circ} \mathrm{C}$ for $1-2$ minutes.

\section{RESULTS AND DISCUSSION}

The powdered roots of $F$. tenuissima were extracted respectively with $n$-hexane, chloroform $\left(\mathrm{CHCl}_{3}\right)$ and methanol $(\mathrm{MeOH})\left(3 \times 2 \mathrm{~L}\right.$, each) by sonification at $30{ }^{\circ} \mathrm{C}$, for 24h. The $\mathrm{CHCl}_{3}$-soluble fraction was subjected to repeated column chromatography (CC) to afford three know compounds (see Figure 1). All of them were daucane type sesquiterpenoids; their structures were established by NMR, MS and by comparison with published data. Compound $\mathbf{1}$ (Teferidin) ${ }^{19}$ and $\mathbf{2}$ (Ferutinin) ${ }^{19}, \mathbf{3}$ (Elaeochytrin A) ${ }^{20}$ were also identified by comparison of their spectral data with those in references. 19,20

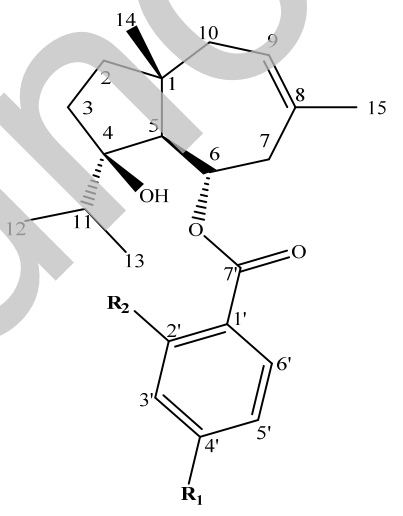

\begin{tabular}{lll} 
Compound & $\mathbf{R}_{\mathbf{1}}$ & $\mathbf{R}_{\mathbf{2}}$ \\
\hline 1-Teferidin & $\mathrm{H}$ & $\mathrm{H}$ \\
\hline 2-Ferutinin & $\mathrm{OH}$ & $\mathrm{H}$ \\
\hline 3-Elaeochytrin-A & $\mathrm{H}$ & $\mathrm{NH}_{2}$
\end{tabular}

Figure-1: Structure of Compounds 1-3 
Table 1: NMR spectroscopic data for compounds 1-3 in $\mathrm{CDCl}_{3}\left(\delta_{\mathrm{H} ;} 7.26 \mathrm{ppm}, \delta_{\mathrm{C}} 77.1 \mathrm{ppm}\right)$

\begin{tabular}{|c|c|c|c|c|c|c|}
\hline \multirow[t]{2}{*}{ Positions } & \multicolumn{2}{|l|}{ Compound -1 } & \multicolumn{2}{|l|}{ Compound -2} & \multicolumn{2}{|l|}{ Compound -3} \\
\hline & $\delta_{\mathrm{H}}(\delta \mathrm{ppm}, J=H z)$ & $\delta_{C}$ & $\delta_{\mathrm{H}}(\delta \mathrm{ppm}, J=H z)$ & $\delta_{C}$ & $\delta_{\mathrm{H}}(\delta \mathrm{ppm}, J=H z)$ & $\delta_{C}$ \\
\hline 1 & - & $43.9(s)$ & - & $44.0(s)$ & - & $44.2(s)$ \\
\hline \multirow[t]{2}{*}{2} & $1.43(m)$ & $41.0(t)$ & $1.56(m)$ & $41.2(t)$ & $1.54(m)$ & $41.5(t)$ \\
\hline & $1.20(m)$ & & $1.26(m)$ & & $1.30(m)$ & \\
\hline \multirow[t]{2}{*}{3} & $1.92(m)$ & $32.4(t)$ & $1.92(m)$ & $31.4(t)$ & $1.91(m)$ & \\
\hline & $1.50(m)$ & & $1.65(m)$ & & $1.60(m)$ & \\
\hline 4 & - & $85.1(s)$ & - & $87.0(s)$ & - & $86.5(s)$ \\
\hline 5 & $1.96(d, J=9.6)$ & $59.4(d)$ & $2.02(d, J=10.8)$ & $60.1(d)$ & $2.00(d, J=10.8)$ & $60.1(d)$ \\
\hline 6 & $5.09(t d, J=10.2,2.4)$ & $70.9(d)$ & $5.27(t d, J=10.4,2.8)$ & $71.2(d)$ & $\begin{array}{l}5.27(d d d, \\
J=10.8,10.4,2.8)\end{array}$ & $70.7(d)$ \\
\hline \multirow[t]{2}{*}{7} & $\begin{array}{l}2.39(d d, \\
J=12.8,10.8)\end{array}$ & $41.5(t)$ & $\begin{array}{l}2.56 \\
(d d, J=12.4,11.2)\end{array}$ & $41.4(t)$ & $\begin{array}{l}2.54(d d, J=12.4,11.6) \\
2.27(d d, J=14.0,2.4)\end{array}$ & $41.6(t)$ \\
\hline & $\begin{array}{l}2.16(d d, \\
J=14.0,12.8)\end{array}$ & & $\begin{array}{l}2.29(d d, \\
J=14.0,2.8)\end{array}$ & & & \\
\hline 8 & - & $133.7(s)$ & - & $\begin{array}{l}133.5 \\
(s)\end{array}$ & - & $\begin{array}{l}134.4 \\
(s)\end{array}$ \\
\hline 9 & $5.50(b s)$ & $\begin{array}{l}125.3 \\
(d)\end{array}$ & $5.55(b t, J=5.6)$ & $125.3(d)$ & $5.55(b s)$ & $\begin{array}{l}125.4 \\
(d)\end{array}$ \\
\hline \multirow[t]{2}{*}{10} & $1.96(m)$ & $40.9(t)$ & $2.06(m)$ & $41.0(t)$ & $2.05(m)$ & $41.2(t)$ \\
\hline & $1.85(m)$ & & $1.98(m)$ & & $1.91(m)$ & \\
\hline 11 & $2.10($ sept $J=6.8)$ & $36.5(d)$ & $1.86($ sept,$J=6.8)$ & $37.0(d)$ & $2.04(m)$ & $37.4(d)$ \\
\hline 12 & $0.75(d, J=6.8)$ & $18.1(q)$ & $0.85(d, I=6.8)$ & $17.6(q)$ & $0.85(d, J=6.8)$ & $17.7(q)$ \\
\hline 13 & $0.94(d, J=6.8)$ & $18.8(q)$ & $0.94(d, J=6.8)$ & $18.5(q)$ & $0.95(d, J=6.8)$ & $18.7(q)$ \\
\hline 14 & $1.01(\mathrm{~s})$ & $20.0(4)$ & $1.10(s)$ & $20.2(q)$ & $1.11(s)$ & $20.3(q)$ \\
\hline 15 & $1.75(\mathrm{~s})$ & $26.6(q)$ & $1.81(s)$ & $26.4(q)$ & $1.82(s)$ & $26.6(q)$ \\
\hline $1^{\prime}$ & - & $131.3(s)$ & - & $121.9(s)$ & - & $\begin{array}{l}111.0 \\
(s)\end{array}$ \\
\hline $2^{\prime}$ & $7.89(d, J$ & $129.3(d)$ & $7.92(d, J=8.8)$ & $132.0(d)$ & - & $\begin{array}{l}151.1 \\
(s)\end{array}$ \\
\hline $3^{\prime}$ & $7.50(d d, J=8.0,7.2)$ & $129.0(d)$ & $6.88(d, J=8.8)$ & $\begin{array}{l}115.5 \\
(d)\end{array}$ & $6.67(d d, J=8.0,0.8)$ & $\begin{array}{l}117.0 \\
(d)\end{array}$ \\
\hline \multirow[t]{4}{*}{$4^{\prime}$} & $7.61(t, J=7.2)$ & $133.3(d)$ & - & $161.1(s)$ & $7.27(d d d, J=7.2,6.8,1.6)$ & $\begin{array}{l}133.7 \\
(d)\end{array}$ \\
\hline & $7.50(d d, J=8.0,7.2)$ & $129.0(d)$ & $6.88(d, J=8.8)$ & $115.5(d)$ & $6.64(t d, J=8.0,1.2)$ & $\begin{array}{l}116.4 \\
(d)\end{array}$ \\
\hline & $7.89(d, J=7.2)$ & $129.3(d)$ & $7.92(d, J=8.8)$ & $132.0(d)$ & $7.78(d d, J=8.0,1.6)$ & $\begin{array}{l}131.0 \\
(d)\end{array}$ \\
\hline & - & $165.2(s)$ & - & $167.3(s)$ & - & $\begin{array}{l}168.3 \\
(s)\end{array}$ \\
\hline
\end{tabular}

F. tenuissima showed a profile of chloroform extracts with UV active at 254 and $366 \mathrm{~nm}$, blue-greencolor visible spots with vanillin / $\mathrm{H}_{2} \mathrm{SO}_{4}$ reagent for all compounds. 


\section{Compound 1 (Teferidin)}

$4 \beta$-Hydroxy-6a-benzoyloxy-5 $\alpha(H)$-dauc-8-ene: Yellow residue, The EI MS/MS, $[\mathrm{M}]^{+}$at $\mathrm{m} / \mathrm{z}=342.16$ for $\mathrm{C}_{22} \mathrm{H}_{30} \mathrm{O}_{3} ;{ }^{1} \mathrm{H},{ }^{13} \mathrm{C}$ NMR spectroscopic data, see Table 1.

Compound 2 (Ferutinin)

$4 \beta$-Hydroxy- $6 \alpha$-( $p$-hydroxybenzoyloxy)-5a(H)-dauc-8-ene:Yellow residue, The El MS/MS $[\mathrm{M}+\mathrm{H}]^{+}$at $\mathrm{m} / \mathrm{z}=359.06,\left[\mathrm{M}+\mathrm{NH}_{4}\right]^{+} \mathrm{m} / \mathrm{z}=376.11,[\mathrm{M}+\mathrm{Na}]^{+} \mathrm{m} / \mathrm{z}=381.06$, $[\mathrm{M}+\mathrm{K}]^{+} \mathrm{m} / \mathrm{z}=397.03$ for $\mathrm{C}_{22} \mathrm{H}_{30} \mathrm{O}_{4} ;{ }^{1} \mathrm{H},{ }^{13} \mathrm{C}$ NMR spectroscopic data, see Table 1.

Compound 3 (Elaeochytrin-A)

$4 \beta$-Hydroxy -6a-(o-aminobenzoyloxy)-5a(H)-dauc-8-ene. Yeliow residue, The El MS $[\mathrm{M}+\mathrm{Na}]{ }^{+} \mathrm{m} / \mathrm{z}=380.34$ for $\mathrm{C}_{22} \mathrm{H}_{31} \mathrm{NO}_{3} ;{ }^{1} \mathrm{H},{ }^{13} \mathrm{C}$ NMR spectros copic data, see Table 1.

All compounds isolated from $F$. tenuissima were evaluated for their cytotoxic activity against PC-3 cancer cell and normal prostat RWPE cell lines. The $\mathrm{IC}_{50}$ of compounds that are active on at least one cell line at concentration are given in Table 2 .

Table 2: Cytotoxicity $\left(\mathrm{IC}_{50}\right.$ in $\left.\mu \mathrm{M}^{\mathrm{a}}\right)$ of isolated jaeschkeanadiol esters against prostat cancer cell lines in vitro

\begin{tabular}{|c|c|c|}
\hline & PC-3 & RWPE-1 \\
\hline Teferidin & $65,3 \pm 4.10$ & $21,77 \pm 1.20$ \\
\hline Ferutinin & $19,69 \pm 2.22$ & $3,295 \pm 0.80$ \\
\hline Elaeochytrin-A & $44,23 \pm 3.27$ & $8,299 \pm 0.9$ \\
\hline Doxorubucinb & $1,17 \pm 0,12$ & $0,468 \pm 0,038$ \\
\hline
\end{tabular}

\section{CONCLUSION}

Mono, di, triesters of humulane, germacrane, eudasmane and especially daucane type sesquiterpenes and coumarin and lactone derivates are major components of Ferula L. genus. ${ }^{22}$ It was observed that the location of the double bond in the daucane ring affected activity, which was between positions 7-8, 8-9 and 9-10. Furthermore, the presence of hydroxyl groups at different positions on daucane ring and the formation of mono, di, tri-ester structures of this hydroxyl group, especially benzoic, angelic, 
cinnamic and vanillic acid increases the variability in biological activity. ${ }^{22}$ The isolated teferidin compound is jaeschkeanadiol benzoic acid ester isolated from $F$. tenuisecta roots for the first time in $1976 .{ }^{21}$ It has also been reported from F. hermonis, F. pallida. F. elaeochytris, F. rigidula, F. jaeschkeana roots. ${ }^{22}$ Ferutinin was first described in 1973 by Saidkozev A. as jaeschekeanadiol p-hydroxy benzoic ester. ${ }^{23}$ It is isolated from different Ferula species previously. ${ }^{23}$ Elaeochytrin-A was first reported from $F$. elaeochytris roots. ${ }^{20}$

In our study, it was determined that all compounds were moderately effective on the PC-3 and RWPE-1 cell line. The affinity of the compounds for RWPE-1 cells also indicated that the selectivity of the compound is not as much as expected.

In a previous study, Elaeochytrin-A showed cytotoxic effects on K562R (imatinibresistant) human chronic myeloid leukaemia and DA1-3b/M2BCR-ABL (dasatinibresistant) mouse leukemia cell line on $\mathrm{IC}_{50} 12.4$ and $7.8 \mathrm{uM}$ concentration respectively. ${ }^{20}$ In the same study, ferutinin showed cytotoxic activity at ${ } \mathrm{C}_{50}: 25.3$ and $29.1 \mu \mathrm{M}$ and teferidin at IC $50: 55.1$ and $29.5 \mu \mathrm{M}$. When the molecular structures were examined, the double bond between C8/C9 position decreased cytotoxic activity. ${ }^{20}$ Ferutinin has been shown to have antiproliferative effect on colon cancer cell lines of WiDr, COLO320-HSR, LS-174T $\mathrm{T}^{24}$ and to induce apoptosis and intracellular $\mathrm{Ca}^{+2}$ pathway in human Jurkat cells. ${ }^{25}$ Ferutinin showed an ERa and ER $\beta$ agonist and antagonist receptor activity with improving sexual function in male and female rats. ${ }^{26} \mathrm{It}$ has been found that the hydroxyl group at position 3 increases the estrogen-like effect of the presence of oxygen and the presence of electrophilic groups in the $p$-position of the benzene ring (hydroxyl, oxo etc.). ${ }^{26}$ Prostate cancer formation; especially androgenic hormones; is the main cause of uncontrolled proliferation of cells. Ferutinin molecule studies suggest that both the effects on sexual function and the activity of in vitro cytotoxicity studies may be specific antagonist/ agonist effects on androgen hormone receptors. ${ }^{26}$ As a result of the our bioactivity studies on the PC-3 cell line with compounds isolated from $F$. tenuisssima roots, the most active cytotoxic agent of ferutinin synthesis emerged (IC50: 19,69 $\mu \mathrm{M})$. In addition to the potential phytotherapeutic of phytochemical and bioactivity studies of other genus-related species due to the biological activity of the root extracts of the Ferula taxa and daucane type sesquiterpenoids.

A cknowledgements: We thank Prof Dr. Erdal BEDiR, Assoc. Prof. Serdar Gokhan Senol, Assoc. Prof Bintuğ Öztürk for their supports. This research project was supported by the Scientific Research Projects Directorate of Ege University (Project No: 13-ECZ-022).

Conflict of interest statement: The authors declare no conflict of interest. 


\section{REFERENCES}

1. Siegel RL, Miller KD, Jemal A. Cancer statistics, 2016. CA: a cancer journal for clinicians. 2016;66(1):7-30.

2. Valiahdi SM, Iranshahi M, Sahebkar A. Cytotoxic activities of phytochemicals from Ferula species. Daru. 2013;21(1):39.

3. Sağıroğlu M. Türkiye Ferula L. (Umbelliferae) Cinsinin Revizyonu [Doktora]. Ankara: Gazi Üniversitesi, Fen Bilimleri Enstitüsü; 2005.

4. Baytop T. Türkiye'de Bitkilerle Tedavi (Geçmişte ve Bügün) 2. Baskı ed. İstanbul: Nobel Tıp Kitabevleri; 1999.

5. Abd El-Razek MH, Ohta S, Hirata T. Terpenoid coumarins of the genus Ferula L. Heterocycles. 2003;60(3):689

6. Wang ZQ, Huang C, Huang J, Han HY, Li GY, Wang JH, et al. The stereochemistry of two monoterpenoid diastereomers from Ferula dissecta. Rsc Advances. 2014;4(28):14373-7.

7. Alkhatib R, Hennebelle T, Joha S, Roumy V, Guzel Y, Biabiany M, et al. Humulane and Germacrane Sesquiterpenes from Ferula lycia. Journal of Natural Products. 2010;73(4):780-3.

8. Galal AM, Abourashed EA, Ross SA, EISohly MA, Al-Said MS, El-Feraly FS. Daucane sesquiterpenes from Ferula hermonis. Journal of Natural Products. 2001;64(3):399-400.

9. Iranshahi M, Amin GR, Amini M, Shafiee A. Sulfur containing derivatives from Ferula persica var. latisecta. Phytochemistry. 2003;63(8):965-6.

10.Duan H, Takaishi $Y$, Tori M, Takaoka S, Honda G, Ito M, et al. Polysulfide derivatives from Ferula foetida. J Nat Prod. 2002;65(11):1667-9.

11. Diaz JG, Fraga BM, Gonzalez AG, Gonzalez P, Hernandez MG, Miranda JM. Triterpenes from Ferula linkii. Phytochemistry. 1984;23(7):1471-3.

12. Suzuki K, Okasaka M, Kashiwada $Y$, Takaishi $Y$, Honda G, Ito M, et al. Sesquiterpene lactones from the roots of Ferula varia and their cytotoxic activity. Journal of Natural Products 2007;70(12):1915-8. 
13. Bagheri SM, Rezvani ME, Vahidi AR, Esmaili M. Anticonvulsant effect of Ferula assa-foetida oleo gum resin on chemical and amygdala-kindled rats. North American Journal of Medical Sciences. 2014;6(8):408-12.

14. Liu T, Osman K, Kaatz GW, Gibbons S, Mu Q. Antibacterial sesquiterpenoid derivatives from Ferula ferulaeoides. Planta Medica. 2013;79(8):701-6.

15. Bashir S, Alam M, Adhikari A, Shrestha RL, Yousuf S, Ahmad B, et al. New antileishmanial sesquiterpene coumarins from Ferula narthex Boiss. Phytochemistry Letters. 2014;9:46-50.

16. Yusufoglu HS, Soliman GA, Abdel-Rahman RF, Abdel-Kader MS, Ganaie MA, Bedir E, et al. Antihyperglycemic and Antihyperlipidemic Effects of Ferula duranii in Experimental Type 2 Diabetic Rats. International Journal of Pharmacology. 2015;11(6):532-41.

17. Yusufoglu HS, Soliman GA, Abdel-Rahman RF, Abdel-Kader MS, Ganaie MA, Bedir E, et al. Antihyperglycemic and antihyperlipidemic effects of Ferula assafoetida and Ferula tenuissima extracts in diabetic rats. Pakistan Journal of Biological Sciences. 2015;18(7):314-23

18. Yusufoglu HS, Soliman GA, Abdel-Rahman RF, Abdel-Kader MS, Genaie MA, Bedir E, et al. Antioxidant an Antihyperglycemic Effects of Ferula drudeana and Ferula huber-morathii in Experimental Diabetic Rats. International Journal of Pharmacology. 2015;11(7):738-48.

19. Al-Oqail M, Hassan WH, Ahmad MS, Al-Rehaily AJ. Phytochemical and biological studies of Solanum schimperianum Hochst. Saudi pharmaceutical journal: SPJ:the official publication of the Saudi Pharmaceutical Society. 2012;20(4):371-9.

20. Alkhatib R, Hennebelle T, Joha S, Idziorek T, Preudhomme C, Quesnel B, et al. Activity of elaeochytrin A from Ferula elaeochytris on leukemia cell lines. Phytochemistry. 2008;69(17):2979-83.

21. Saidkhodzhaev A, Nikonov GK. The structure of teferidin - A new ester from the fruit of Ferula tenuisecta. Chemistry of Natural Compounds. 1976;12(1):967.

22. Shakhnoza S. Azimova AIS. Natural Sesquiterpene Esters; Plant Sources, Structure and Properties. Springer, New York 2013.

23. Saidkhodzhaev A, Nikonov GK. The structure of Ferutinin, Chemistry of Natural Compounds. 1975;9(1):25-6. 
24.Poli F, Appendino G, Sacchetti G, Ballero M, Maggiano N, Ranelletti FO. Antiproliferative effects of daucane esters from Ferula communis and $F$. arrigonii on human colon cancer cell lines. Phytotherapy Research. 2005;19(2):152-7.

25. Macho A, Blanco-Molina M, Spagliardi P, Appendino G, Bremner P, Heinrich M, et al. Calcium ionophoretic and apoptotic effects of ferutinin in the human Jurkat T-cell line. Biochemical Pharmacology. 2004;68(5):875-83.

26. Appendino G, Spagliardi P, Cravotto G, Pocock V, Milligan S. Daucane phytoestrogens: A structure-activity study. Journal of Natural Products. 2002;65(11):1612-5. 